\title{
Daniela Omlor
}

Michael Newman, Six Authors in Search of Justice: Engaging with Political Transitions (London: Hurst and Company, 2016), 315 pp., £20 (hbk) ISBN 9781849046329

In Six Authors in Search of Justice, Michael Newman proposes a difficult, cross-disciplinary balancing act between the fields of political science and literature. Although his primary aim is to focus on problems of justice and injustice in the context of a variety of political transitions, he proposes to do so by analysing the works of six different writers and their evolving understanding of justice. As a caveat, Newman states that his book does not constitute 'a work of literary criticism or cultural studies because the writings are considered largely for the light that they throw on political and ethical issues' (p. 1). Yet, as any literary scholar will be too aware, to disentangle literature and politics, fiction and non-fiction can be a critical undertaking fraught with difficulties.

The six authors selected are Victor Serge, Albert Camus, Ngũgĩ wa Thiong'o, Jorge Semprún, Ariel Dorfman and Nadine Gordimer, who are each dealt with in a separate chapter. Newman points out that the situations these authors confronted differed greatly but that they also shared common characteristics such as their left-leaning politics and their position simultaneously on the inside and outside of the (dictatorial) societies about which they were writing. He also briefly touches on the question of historical truth as opposed to literary truth. Furthermore, Newman advocates a liberal use of the term justice, following the ideas of Amartya Sen and Eric Heinze, avoiding a limiting definition that would simply consider justice the opposite of injustice. Underlining that the discussed authors' understanding of justice was fluid and changing, Newman then proposes six types of justice: namely, a liberal conception of justice, social justice, a Marxist view of class and justice, legal justice, historical justice and, lastly, transitional justice. 
The chapter on Victor Serge, born in Belgium of Russian parents, opens with the observation that perceptions of the Bolshevik revolution are now inevitably tainted by our knowledge of the Stalinist regime that followed. In his discussion of a range of Serge's writings on the backdrop of his life, Newman shows how the once passionate revolutionary who defended the use of violence and terror in the name of revolution came to see the importance of individual freedom by 1928, moving from a Marxist ideal of justice to one that embraced social justice and more humane values. This would have offered an interesting point for comparison with Semprún's shifting viewpoint too. In particular, Serge came to believe that the death penalty embodied repressive values beyond the legal realm. From this it can be extrapolated that Serge ended up viewing the death sentence in moral rather than legal terms, which actually raises the question of the complexities of the concept of justice, which constantly eschews an either purely legal or moral definition.

This last point concerning the death penalty is a conviction that Serge held in common with Albert Camus, to whom the next chapter is dedicated. Camus' stance is traced from his opposition to the Nazi occupation of France through the purges after the war to his rejection of an independent Algeria. Quite rightly, Newman underlines that for Camus the issues that were central in texts such as The Outsider or The Plague were never just political but also moral. Newman believes that it was above all Camus' experience of the post-war purges which led to his preoccupation with morality gaining centre stage. It is this focus on absolute values which Newman blames for Camus' untenable attitude towards the decolonisation of Algeria. This is a point it would have been worth exploring further through in-depth interpretations of relevant texts and perhaps also in relation to other contemporary French intellectuals, such as Sartre, who were acting within and reacting to similar political and historical realities as Camus. 
The Kenyan Ngũgĩ wa Thiong'o is the third author under scrutiny. Newman illustrates his shifting deliberations on colonial injustices through the use of memory and history and also emphasises the significance of the choice of language in which Ngũgĩ was writing. Newman poses the question 'whether Ngũgĩ was now using history to promote a view that conformed to a particular national and revolutionary narrative' (p. 105) by revising A Grain of Wheat in 1970 in order to counter the colonial representation of the Mau Mau guerrillas. While Newman concedes that it would be wrong to consider Ngũgĩ primarily as a political commentator, since it is mainly through his creative works that he explores the themes of justice, injustice and transition, a more detailed engagement with how he achieves this by using non-realist techniques would have been fruitful. Poetic justice might have been another term that could have come in useful here.

Newman turns his attention to Jorge Semprún in the following chapter. Exiled in France as a result of the Spanish Civil War, Semprún was initially a fervent Communist and as such joined the French Resistance. However, dedicating himself to literature after his expulsion from the Spanish Communist Party in the sixties, 'he came to regard Soviet communism and Nazism as twin (though not identical) forms of "radical evil"” (p.134), which meant that his hopes for a Spain liberated from Franco's dictatorship were also changing. In Newman's view, Semprún agreed with the majority who saw the transition to democracy as positive, including the amnesty it entailed, and only later came to regret the collective amnesia after serving as a Minister of Culture in Felipe González's cabinet. Yet in his Autobiografía de Federico Sánchez from 1978, Semprún had already lamented the lack of memory or 'desmemoria' predominant in the Communist Party at a critical moment for the establishment of a Spanish democracy. Newman is right though to criticise Semprún for focusing on past injustices at the cost of abandoning future projects for the transformation of 
society, noting that Semprún had come full circle and returned to some of the more liberal, less radical, ideas of justice held by his father.

Ariel Dorfman and his political evolution prior to and in the wake of Allende's presidency, Pinochet's coup and Chile's return to democracy form the nucleus of the next chapter. From political activist, Dorfman's role changed in exile into that of a public intellectual, focusing on his creative writing to address issues such as the struggle for justice for the disappeared and the dead. Newman traces Dorfman's belief that genuine dialogue and multiple perspectives were necessary to accomplish this in his use of multiple narrative voices. This is an interesting idea that could have been given more prominence in the analysis. The same is true for the ambiguity of interpretation inherent in Death and the Maiden, which requires an active response from the spectator, perhaps leading to the larger question why political activists might be tempted to turn to literature or culture over politics.

The final author considered is Nadine Gordimer, who initially thought that apartheid could be ended through interpersonal relations and preferred the notion of a 'non-racial' South Africa. She also accepted the necessity for violence as part of the fight against apartheid. Even though she was convinced that the writer's duty was above all to society she did not think that artistic integrity should be sacrificed to this end. Again, Newman points out the use of different 'voices' that she makes in Burger's Daughter. Unlike some of the other authors discussed it is stressed that 'she was far less inclined to adopt the kind of moral absolutism that they did in their disappointment. She had no doubt that the fight against apartheid was just and she pragmatically accepted the necessity for violence, but she never believed that everyone in the liberation movement was "pure" or heroic' (p. 212).

On many levels, Newman's book is a brave endeavour. It represents a tour de force of six very different historical transitions and six very different authors of fiction engaging with this experience. It thus raises valid questions about the importance of justice for their works 
and the ways in which literature might shape society's view of justice. This broad approach naturally has its limitations and the book is perhaps best thought of as a valuable survey that offers a good starting point for further in-depth study of this thematic as well as valid points of comparison between the different writers. Did gender or language choice have a bearing on how these writers approached their circumstances? By definition, the book straddles the line between political science and literature uneasily at times; certainly from the point of view of literary scholars more insights on testimony, truth and justice in the literary realm would have been desirable as well as a sustained exploration of the ways in which the authors' stylistic choices might be revealing in this regard.

Daniela Omlor, Lincoln College,

University of Oxford 